\title{
Enzyme kinetics of RNase present in testes
}

\begin{abstract}
RNase A is one of the secretary enzymes of pancreas and secreted in to the digestive tract for digestion of RNA present in the food. In RNaseA super family RNase H2 was known to involve in protection against chromosomal instability in yeast strains where as in male wistar rats testes by RNaseA. Drug Metosartan was proven to cause chromosomal instability in testes. So, identification of RNase present in testes proven to be useful as it protects testes against chromosome instability. Column chromatography was one of the techniques used here to isolate RNase present in the testes and enzyme kinetics was performed with column isolated enzyme to know the inhibition pattern of the enzyme, and to find $\mathrm{K} 0.5$ and Vmax.
\end{abstract}

Volume 3 Issue 4 - 2018

\author{
Eswari Beeram,' Divya Bysani, ${ }^{2}$ Pallavi C, ${ }^{2}$ \\ Thyagaraju $\mathrm{K}^{3}$ \\ 1,2Department of biochemistry, Sri Venkateswara University, India \\ ${ }^{3}$ Sri Venkateswara University, India
}

Correspondence: Eswari Beeram, Department of biochemistry, Sri Venkateswara University, Tirupati, Andhra Pradesh, India, 517502, Tel 9700277136,

Email eshu.sonu@gmail.com

Received: June 13,2018| Published: July 16, 2018

\section{Introduction}

Enzyme kinetics is one of the important parameter to be studied to know the inhibition studies of RNase A. RNase A is an allosteric enzyme which consists of an allosteric site in addition to the active site of the enzyme. With respect to allosteric enzymes two types of modulators namely positive and negative regulates the enzyme. Positive allosteric modulators increase the cooperitivity to other sites in positive manner for a multi subunit protein. So, K0.5 is usually decreased and Vmax found to be increased. ${ }^{1}$ Where as negative modulators decrease the affinity of substrate binding at one subunit of enzyme compared to other subunits of it. So, K0.5 found to be increased and Vmax decreases. ${ }^{1} \mathrm{O} 2$ binding to the $\mathrm{Hb}$ is an example of positive cooperivity and feedback inhibition by allosteric enzyme is an example of negative cooperitivity. UV visible spectroscopic analysis in vitro proved RNase A is an allosteric enzyme and agarose gel electrophoresis analysis ${ }^{2}$ has proved that metosartan is an inhibitor of RNase A. Various plots of enzyme like Michaelis-Menton plot, Line weaver- burk plot, Dixon plot and Eadie- hofstee plot are used to know the K0.5 and Vmax of the enzyme in the presence and absence of drug. As RNase A is an allosteric enzyme it doesn't follows Michaelsmenton kinetics as it consists of more than one active site. Allosteric enzymes give profound sigmoid curve with negative modulator and hyperbolic curve with positive modulator. Line weaver - Burk plot is not useful in case of allosteric enzymes to know whether the inhibition pattern is allosteric or not. Dixon plots are used to know the potency of inhibitor over the enzyme and Eadie - Hofstee plot is useful to know the $\mathrm{Km} / \mathrm{Vmax}$ and $\mathrm{Km}$. But it is difficult to know the $\mathrm{Km}$ and Vmax of the enzymes by Eadie- Hofstee plot. Enzyme kinetics for each concentration is plotted and its effect of drug on enzyme was studied. The term $\mathrm{Km}$ is not used for allosteric enzymes instead K0.5 is used as the enzyme doesn't follows Michaels menton kinetics. Properties of allosteric enzymes are as follows. Higher substrate concentration favours R state of the enzyme where as lower concentration favours $\mathrm{T}$ state where as other molecules like $\mathrm{O} 2$ and 2,3-Bis phosphor glycerate are regulators of allosteric enzymes.

\section{Material and methods}

\section{Isolation of enzyme from source}

The protocol was per Larry Klinet et al. ${ }^{3}$ All the procedure is carried out at room temperature as RNase A is resistant to high temperatures. Testes were dissected, washed in distilled water to remove blood and grinded in $30 \mathrm{ml}$ of buffer A $(0.05 \mathrm{M}$ tris- HCL ( $\mathrm{PH} 8.0$ ), 0.01M magnesium chloride, $0.01 \mathrm{M} \beta$ - mercaptoethanol, $0.10 \mathrm{mM}$ EGTA, $10 \%(\mathrm{~V} / \mathrm{V})$ glycerol+0.05M KCL) with mortar and pestle and centrifuged at $8000 \mathrm{~g}$ for $10 \mathrm{~min}$.. Supernatant was collected and centrifuged at $12,000 \mathrm{rpm}$ for $3 \mathrm{hrs}$ and the resulting fraction was applied to the DEAE cellulose column.

\section{DEAE cellulose chromatography}

The protocol was per Larry Klinet et al. ${ }^{3}$ After isolation of the enzyme from source fraction obtained above was subjected to DEAE cellulose column chromatography. Column prepared was equilibrated with buffer $\mathrm{A}+0.05 \mathrm{M} \mathrm{Kcl}$ and washed with the same maintaining flow rate of $130 \mathrm{ml} / \mathrm{hr}$. The eluted fractions are pooled and saturated with $70 \%$ Ammoniumsulfate and the resulting solution was centrifuged at $12000 \mathrm{rpm}$ for $20 \mathrm{~min}$. The above sample was subjected to dialysis with buffer $\mathrm{A}+0.05 \mathrm{KCL}$ of 1 liter for $5 \mathrm{hrs}$ until the final volume was about $7.5 \mathrm{ml}$.

\section{DEAE cellulose gradient chromatography}

The protocol was per Larry Klinet et al. ${ }^{3}$ The dialysed fraction was applied to the DEAE cellulose column which was previously equilibrated with buffer A+0.05 M KCL. The sample was eluted with a linear gradient of $0.1-0.30 \mathrm{M} \mathrm{Kcl}$ and the fractions was collected for every $10 \mathrm{~min}$. Dialysis was performed with the above eluted solution against buffer $\mathrm{A}$ for $30 \mathrm{hrs}$ and the buffer was replaced with fresh one for thrice.

\section{Carboxy methyl cellulose column chromatography}

The protocol was as per You Di LIAO \& Jaang Jiun WANG. ${ }^{4}$ The samples that have been eluted from the DEAE chromatography 
was subjected to dialysis, pooled and were loaded on to the carboxy methyl cellulose column which was previously equilibrated with HEPES buffer containing $0.05 \mathrm{M} \mathrm{Kcl}$. The RNase sample was eluted with $300 \mathrm{ml}$ HEPES buffer of linear gradient from $0.05-0.22 \mathrm{M} \mathrm{Kcl}$. The elution profile was monitored by U.V Visible spectroscopy and the resulting fraction was used for enzyme kinetics.

\section{Enzyme kinetics}

$50 \mu 1$ of enzyme isolated by column chromatography was added to $2 \mathrm{ml}$ of substrate concentrations $0.25 \mathrm{mM}, 0.5 \mathrm{mM}$ and $1 \mathrm{mM}$ separately and $50 \mu 1$ of drug $[1.6 \mathrm{mM}, 3.4 \mathrm{mM}, 6.4 \mathrm{mM}]$ was added and decrease in absorbance was recorded at $260 \mathrm{~nm}$ in the presence and absence of drug. The absorbance was recorded up to next decreased reading was $\leq 0.001$.

\section{Results}

\section{Michaelis-Menton plots of enzyme RNase A in the absence and presence of drug}

From the (Figure 1) A and 1B K0.5 was found to be 0.04 in the absence of drug and 0.06 in the presence of drug. Whereas Vmax was found to be 1 in the absence of drug and 0.01 in the presence of drug which indicates metosartan is the negative modulator of enzyme RNase A is a heterotropic enzyme.
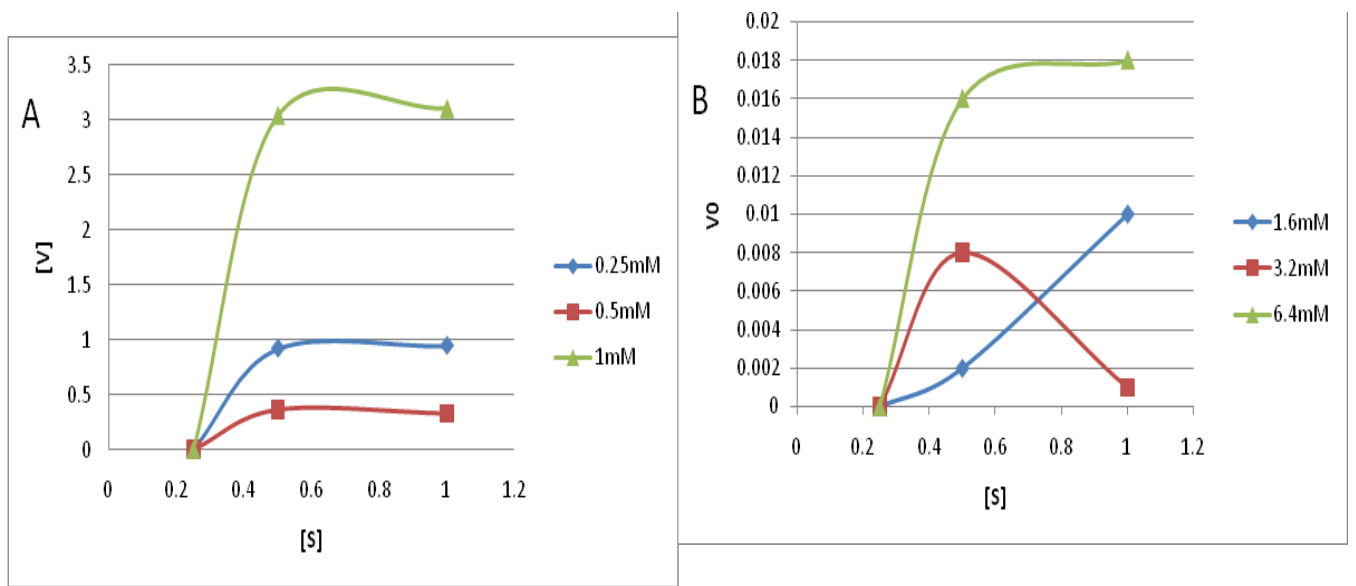

Figure I Michaelis-Menton plot of RNase A. (A) Plot at $1.6 \mathrm{mM}, 3.2 \mathrm{mM}, 6.4 \mathrm{mM}$ concentrations of drug. (B) Plot of RNase+RNA in the absence of drug.
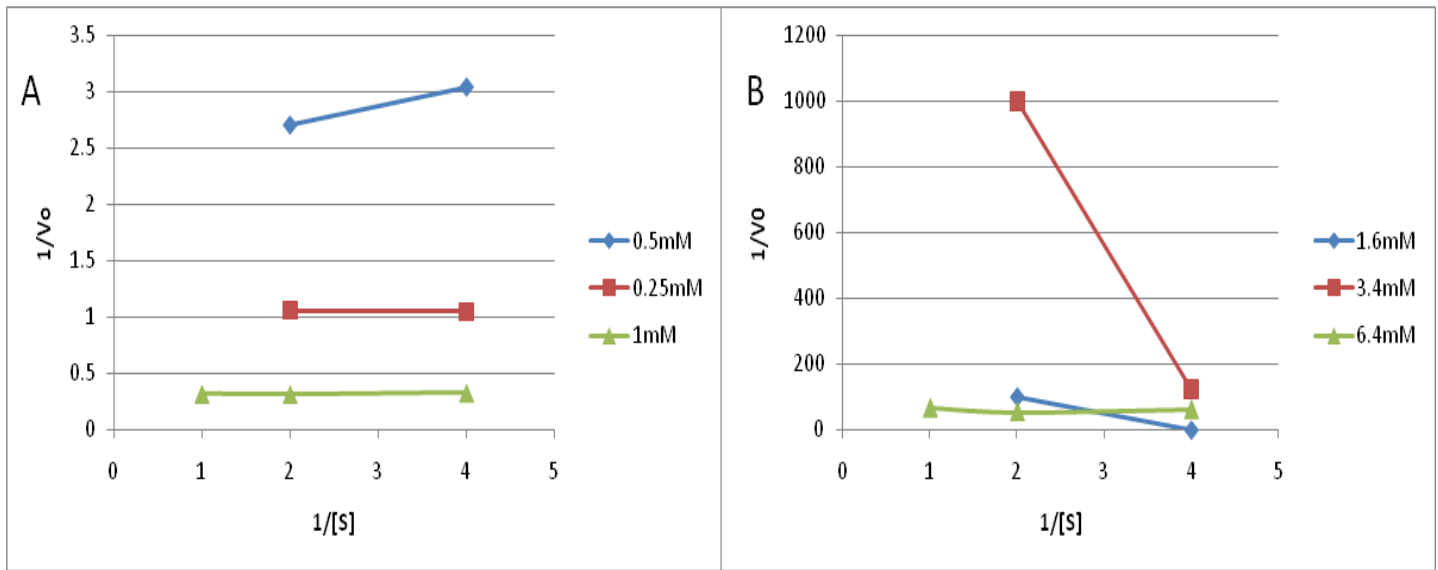

Figure 2 Lineweaver- Burk plots of RNase A. (A) Plot of RNase A+RNA in the absence of drug.(B) Plot of RNase A at I.6mM and 3.2mM concentrations of drug.

From the figure $2 \mathrm{~B}$ the curve exactly matches non competitive inhibition which indicates that the enzyme is inhibited by metosartan non competitively and same was observed with Dixon plots also.

\section{Line weaver- Burk plots of Enzyme RNase $A$ in the presence and absence of drug}

From the (Figure 2) B the curve is sigmoid which indicates that the enzyme is allosteric and same was observed with Dixon plots also. At higher substrate concentration the enzyme found to be favoured in $\mathrm{R}$ state compared to T- state. So, K0.5 and Vmax of the enzyme found to be decreased (Figure 3) (Figure 4). 

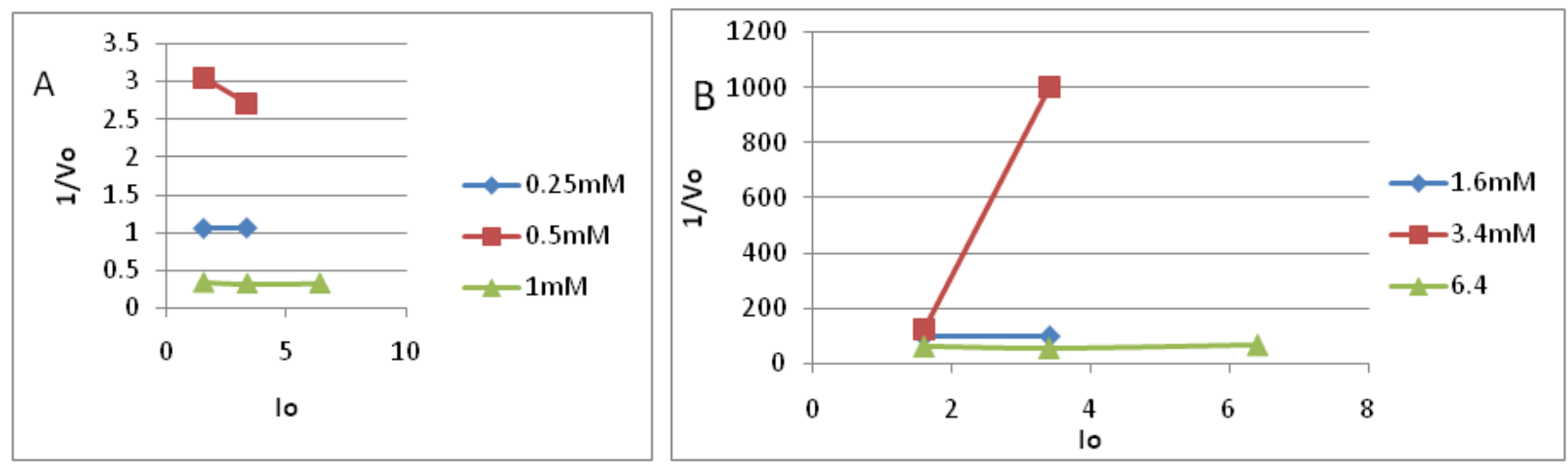

Figure 3 Dixon plots of RNase A. (A) Plot in the absence of drug. (B) are the plots at $1.6 \mathrm{mM}, 3.2 \mathrm{mM}, 6.4 \mathrm{mM}$ concentrations of drug. At 6.4mM concentration the curve is about to be sigmoidal.

\section{Discussion}

Column chromatography was one of the techniques used to isolate RNase present in the testes and enzyme kinetics is one of the parameter to be studied. Various plots of enzyme in presence and absence of drug concluded that RNase A is heterotropic and inhibited by drug metosartan in an allosteric dependent manner. Previous reports of Inhibition studies by UV visible spectroscopy ${ }^{5}$ and immune fluorescence ${ }^{6}$ in vitro confirmed that the enzyme present in testes is RNase A and its presence is intracellular. Allosteric enzymes are regulated by various means like phosphorylation and covalent modification. But in this case the enzyme is inhibited by drug metosartan which is a negative modulator of enzyme. Previous reports have shown that RNase A is active at multimer state compared to monomer and RNase $\mathrm{H} 2$ is involved in protection against chromosomal instability in yeast strains. ${ }^{7}$ Where as in wistar rats the protection against chromosomal instability in testes was done by RNase A. So, by these we can conclude that medication of drug along with RNase A leads to slow release of the drug which results in reduced effects of drug on testes compared to direct intake. ${ }^{8}$

\section{Conclusion}

RNase A is involved in various activities like chromosomal instability, Immune defence and gene regulation etc., but in testes it is mainly involved in chromosomal stability. So, study of inhibitors that acts on enzyme must be studied through kinetics of enzyme. RNase A present in the testes and inhibited by drug metosartan in an allosteric manner by acting as negative modulator of the enzyme.

\section{Acknowledgements}

None.

\section{Conflict of interest}

The author declares there is no conflict of interest.

\section{References}

1. Bhagavan NV, Chung Eun Ha. Chapter 6-Enzymes and Enzyme Regulation Essentials of Medical Biochemistry with Clinical Cases. 2nd ed. $2011 ; 47-58$.

2. Eswari Beeram. Inhibition of RNase by Drug Metosartan in Testis Tissue International Journal of Recent Scientific Research. 2017;8(6):1739417395.

3. Larry Klinet, Satoshi Nishikawa, Dieter. Soil Partial Purification of RNase P from Schizosaccharomyces pombe. The Journal of Biological Chemistry. 1981;256(10):5058-5063.

4. You Di LIAO, Jaang Jiun WANG. Yolk granules are the major compartment for bullfrog (Rana catesbeiana) oocyte-specific ribonuclease. Eur J Biochem. 1994;222(1):215-220.

5. Eswari Beeram, Thyagaraju kedam. Chromatin Integrity In Testis By Microscopy And Drug Inhibition Studies Of RNase A By UV - Visible Spectroscopy. ejbps. 2018;5(1):232-237.

6. Eswari Beeram, Thyagaraju kedam. Examination of Testis for RNase A through Column Chromatography and Immuno fluorescence. ParipexIndian Journal of Research. 2017;6(11):715-716.

7. Zimmer AD, Koshland D. Differential roles of the RNases $\mathrm{H}$ in preventing chromosome instability. Proc Natl Acad Sci USA. 2016;113(43):1222012225 .

8. Berg, Jeremy Mark. Biochemistry /Jeremy M. Berg, John L. Tymoczko, Lubert Stryer. Biochemistry 6th edition. In: Stryer, Lubert, editors. WH Freeman Company. New York: Palgrave; 2007. 